\title{
To the Problem of Rise in the Standard of Living of Population
}

\author{
Yelena I. Baikova ${ }^{1} \&$ Nikolay N. Vardiashvili ${ }^{2}$ \\ ${ }^{1}$ Kostanai branch of Chelyabinsk State University, Kostanay, Kazakhstan \\ ${ }^{2}$ A. Baitursynov Kostanay State University, Kostanay, Kazakhstan \\ Correspondence: Yelena I. Baikova, Kostanai branch of Chelyabinsk State University, 168a Borodina st., \\ Kostanay, 110006, Kazakhstan. E-mail: baikova_elena73@mail.ru
}

Received: October 20, 2014 Accepted: November 13, 2014 Online Published: February 25, 2015

doi:10.5539/ass.v11n6p45 URL: http://dx.doi.org/10.5539/ass.v11n6p45

\begin{abstract}
The problem of the rise in the standard of living of population has pressing character as it is proved in the article. The author also analyses dynamics of standard of living in a certain period in Kazakhstan, Russia as one of the most developed countries of CIS and Canada as one of the most developed countries of the world. Complex approach has been proposed to improve methods of standard of living of population assessment. Calculations to define optimal standard of living of population on an example of Kostanay region of Kazakhstan were made basing on this approach. This research allowed making conclusion on the necessity of more effective utilization of economic capacity of the region to increase the standard of living of population. Proposed approach has universal character and it may be used to analysis and planning of the standard of living of population in regional and country level.
\end{abstract}

Keywords: standard of living, living wage, optimal consumer basket, human potential development index, technique of definition the optimal, level of living

\section{Introduction}

Rise in the standard of living and quality of life of population is one of the most pressing problems nowadays. Economic stability of society depends greatly on solving this problem. Standard of living is the assessment of economical dimension of the quality of life of population and is criterion of choice of directions and priorities of economic and social policy of state. When a state is unable to provide sufficient standard of living and quality of life it cause among other things negative migration balance as "brain drain".

Kazakhstan is not an exception because efforts to improve standard of living of population is one of strategic aims of the country. It is stated in the document "Strategy Kazakhstan-2050: The New Political Course of Matured State". It declared the necessity of establishing of minimal social standards and guarantees directly depending on the growth of the economy and budget (http://www.akorda.kz/ru/page/page_poslanie-prezidenta-respubliki-kazakhstan-lidera-natsii-nursultana-nazarba eva-narodu-kazakhstana).

Scientists differ in their ideas of interpretation of the category "standard of living". To our mind, V. N. Bobkov defined the essence of the concept "standard of living" is defined in the most correct way. He wrote "standard of living in general is monetary assessment of resources necessary to provide quality of life of a person, social groups and society as a whole" (Bobkov, 2009). N. M. Rimashevski gave also exact definition of "standard of living is the complex of conditions of man's functioning in consumption sphere that manifests itself in the scope of development of people's requirements and the character of their satisfaction. Various requirements and necessities arousing and realized in consumption sphere are the backbone foundation" (Rimashevskaya, 1988).

Standard of living assessment is relatively complicated process that on one hand depends on the structure and the scope of requirements of society and on the other hand that is limited by possibilities to satisfy them. In economical literature standard of living is characterized by a number of characteristics: gross national income; real earnings of population; average and minimal salary of workers in different industries; ratio of real earnings per capita, minimal and average salary of workers in different industries; ratio of minimal salary and minimal pension; consumption of food and goods, durable articles by population and housing; costs of facilities; difference in earnings; life interval; education level; structure of consumption of foods and other (Raitsin, 2006; Vishnevskaya, 2014; Andreeva, 2013; Menshikova \& Kopteva, 2012). 


\section{Methodic}

\subsection{Standard of Living Level Assessment}

Cost of living is globally accepted important characteristic among economic factors that characterizes standard of living of population. Cost of living is minimal earning level that is considered to be necessary to provide a certain standard of living in a certain country (Ravallion, 1992). It is worth noting that calculation of the cost of living is made on the base of the consumer basket and approaches to forming of these baskets in global practice are different. In Western tradition cost of living reflects earnings that provide "worthy standard of living" in accordance with prevalent standards of consumption. In the practice of CIS countries cost of living reflects earning level that provide only minimal consumption. Cost of living in the Republic of Kazakhstan is cost estimate of consumer basket including minimal sets of food, goods and services (On approval of the Rules of calculation of the value of cost of living Mutual Order of the Ministry of Labour and social protection of the Republic of Kazakhstan dated December, 22005 \# 307/1-p).

One may make an opinion of standard of living in a country also by the ratio of well-to-do and poor strata. Poverty is complicated social and economic phenomenon of difficulties to satisfy the primary physiological necessities related to realization of the right to living by a certain group of population and lack of possibility to fully participate in social life. There are several approaches to assessment of poverty level: absolute, relative and subjective.

Cost of living is used as criterion of absolute poverty in global practice. Poverty line depends on real economic possibilities of a state and is used only for social protection. Now established poverty line in the Republic of Kazakhstan for provisioning of social aid is $40 \%$ of the cost of living that does not cover spending even on the minimal set of food. So the state guarantees as a social aid not the difference between the cost of living and collected income but the sum it is capable to provide basing on its possibilities.

Relative approach to poverty defines people that have no possibility to live according the most widely accepted in society standards as poor. For example in the USA the line of relative poverty is defined as $40 \%$ of median (average) income; in Europe as 50\%; in Scandinavian countries as 60\% (Reshetnikova, 2012).

Idea of the poverty line in different countries is different. Usually the richer is country the higher is established poverty line. The World Bank has set so called International poverty line. For CIS region including Kazakhstan recommended poverty line equals $\$ 4.3$ per person a day. It defines the level of satisfaction of inalienable needs of a man such as education, health protection, access to information, etc. To compare poverty line in industrially developed countries is $\$ 14.4$ per person a day (World Bank, 2005M).

Besides listed particular indicators integral indicators are being used that allow making intercountry comparisons of standard of living more correctly.

For example, poverty is viewed in relation to economic disparity in society. Gini Index is used as international indicator of population's income distribution. It is defined as deviation scope of actual distribution of population's income from the line of its uniform distribution. For uniform distribution it equals zero and in absolute disparity of distribution is equals one.

Gross national income per capita calculated basing on purchasing-power parity is used as an integral indicator of resource provisioning of standard of living. According to classification of the World Bank on July 1, 2013 there are countries with high income-higher than $\$ 12616$, countries with income higher than average-from $\$ 4086$ to $\$ 12615$, countries with income lower than average-from $\$ 1036$ to $\$ 4085$ and countries with low income-less than $\$ 1035$ (The new countries classification, 2013).

Human potential development index (HPDI) is important indicator that allows comparing standard of living of population of different countries and regions. It is comprised of two elements: life expectancy on the day of birth, population's education level and gross national income (GNI) per capita basing on purchasing-power parity in US dollars. Using HPDI allows evaluate social and economic situation in individual countries and globally and to group countries with high, average and low standard of living (Kosmina, 2009).

All countries are separated into four following groups depending on the standard of living defined by the value of HPDI:

1) very high, HPDI $(0,9-1)$.

2) high, HPDI $(0,8-0,9)$.

3) medium, HPDI $(0,5-0,8)$. 
4) low, HPDI (0-0,5) (Ponomariova, 2011).

\subsection{Assessment of Kazakhstan's Population Standard of Living}

Concepts of human development of Kazakhstan are defined in such strategic documents as "Kazakhstan- 2030", "Kazakhstan-2050", national, regional, industry specific programs and plans including those focused on decrease of poverty line, improvement of health and education of the population (Turliybekova, Ikmatova, \& Ikmatova, $\mathrm{n}$. d.). These documents formulate target reference points for achieving indicators of the level of income and the quality of life typical for developed economies. So it is important to define the place of Kazakhstan basing on these key indicators of the quality of life and standard of living.

Table 1 is an example of definition of Kazakhstan's place in the world by HPDI, GNI per capita based on purchasing-power parity and Gini Index. Kazakhstan is compared with Canada and Russia because these countries have similar climate conditions, vast territory with low population density. Besides Canada is developed country.

Table 1. Kazakhstan's place in the world by HPDI, GNI per capita and Gini index

\begin{tabular}{|c|c|c|c|c|c|c|c|c|c|}
\hline \multirow{3}{*}{ Indicator } & \multicolumn{9}{|l|}{ Years } \\
\hline & \multicolumn{3}{|l|}{2011} & \multicolumn{3}{|l|}{2012} & \multicolumn{3}{|l|}{2013} \\
\hline & Kazakhstan & Russia & Canada & Kazakhstan & Russia & Canada & Kazakhstan & Russia & Canada \\
\hline Rank place by HPDI & 68 & 66 & 6 & 69 & 55 & 11 & 70 & 57 & 8 \\
\hline HPDI & 0.745 & 0.755 & 0.908 & 0.754 & 0.788 & 0.911 & 0.757 & 0.778 & 0.902 \\
\hline $\begin{array}{l}\text { GNI per capita based } \\
\text { on purchasing-power } \\
\text { parity, }(\$)\end{array}$ & 10585 & 14561 & 35166 & 10451 & 14461 & 35369 & 19441 & 22617 & 41887 \\
\hline Gini Index, $\%$ & 30.9 & 42.3 & 32.6 & 29 & 42 & 32.6 & 27.6 & 42 & 32.6 \\
\hline
\end{tabular}

*Note: based on sources Human Development Report, 2011; Report on human development, 2013; Human Development Report, 2014.

According data of table 1 rate of economic growth has been decreasing in Kazakhstan in 2012, GNI per capita based on purchasing-power parity decreased although HPDI grow a little. As a result in the rating of countries by HPDI Kazakhstan in 2012 moved from $68^{\text {th }}$ place (that the country has in 2011) to $69^{\text {th }}$ place. In 2013 GNI per capita based on purchasing-power parity has grown by $86 \%$ and was $\$ 19441$. HPDI has grown slightly from 0,003 to 0,757 . Still in this rating Kazakhstan moved one position lower to $70^{\text {th }}$ place.

Graphic of HPDI dynamics starting form 2000 is shown in Figure 1.

One may consider decreasing of economic disparity in cash income proved by Gini Index as positive trend.

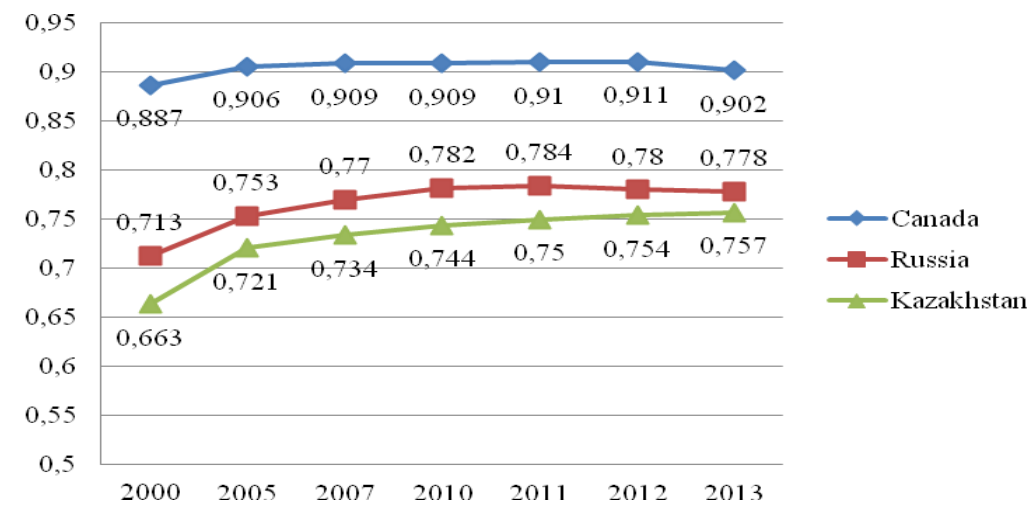

Figure 1. HPDI dynamics in Kazakhstan, Russia and Canada

Kazakhstan may be viewed as the country with average standard of living of population basing on the value of HPDI.

Advantage of this index is relative simplicity of calculation and availability of data. 


\subsection{Complex Assessment of Standard of Living of Population of Kazakhstan}

Economic prosperity does not always correspond to index of human potential development. According to the data for 2012103 of 187 countries have higher place in the world by HPDI than by GNI per capita that indicates high efficiency of efforts of these countries to "convert" earnings into development of human potential. To the contrary, 78 rating HPDI is lower that GNI per capita. That means that these countries use economic prosperity to improve the life of population with lower effectiveness. Kazakhstan's ratings by HPDI and GNI per capita differ slightly. In 2011 the country has 68 place by HPDI and 72 by GNI, in 2012-69 place by HPDI and 77 by GNI.

Rating of countries by standard of living according The Legatum Prosperity Index Table Rankings is shown in Table 2 .

Table 2. Standard of living of population of countries of the world

\begin{tabular}{|c|c|c|c|c|c|c|c|c|c|}
\hline \multirow{3}{*}{ Indicators } & \multicolumn{3}{|c|}{ Kazakhstan } & \multicolumn{3}{|c|}{ Russia } & \multicolumn{3}{|c|}{ Canada } \\
\hline & & & & & years & & & & \\
\hline & 2011 & 2012 & 2013 & 2011 & 2012 & 2013 & 2011 & 2012 & 2013 \\
\hline \multicolumn{10}{|l|}{ Rating } \\
\hline Standard of living & 46 & 46 & 47 & 59 & 66 & 61 & 6 & 6 & 3 \\
\hline $\begin{array}{l}\text { By Indicators of standard of living: } \\
\text { Economy }\end{array}$ & 56 & 54 & 45 & 72 & 62 & 50 & 5 & 8 & 4 \\
\hline Entrepreneurship and innovations & 60 & 59 & 55 & 50 & 50 & 47 & 9 & 16 & 16 \\
\hline Govering & 80 & 95 & 97 & 96 & 118 & 115 & 5 & 6 & 8 \\
\hline Education & 42 & 43 & 41 & 34 & 27 & 26 & 10 & 3 & 3 \\
\hline Life span & 53 & 60 & 60 & 42 & 48 & 44 & 15 & 15 & 11 \\
\hline Safety & 49 & 53 & 66 & 82 & 97 & 98 & 7 & 9 & 7 \\
\hline Personal freedom & 64 & 43 & 52 & 87 & 119 & 114 & 1 & 1 & 1 \\
\hline Social capital & 27 & 37 & 22 & 48 & 71 & 62 & 8 & 8 & 6 \\
\hline
\end{tabular}

* Note: Based on sources: Worldwide cost of living table for 2011, Worldwide cost of living table for 2012; The legatum prosperity index.

This rating includes such factors as salary (included in indicator economy), health care quality, that affects life span, quality of education, freedom for business (entrepreneurship and innovations), safety level, personal freedom and some other factors. In this rating in 2013 Kazakhstan was $47^{\text {th }}$ by standard of living of 142 countries. Kazakhstan is ahead of Russia by such indicators as governing, safety, personal freedom and significantly falls behind by education and life span. In economic development Kazakhstan is ahead of Russia by 5 positions. In general in standard of living comparing with 2012 year, Canada and Russia get ahead by 3 and 5 position, respectively, and Kazakhstan fell behind by 1 position, although rose by 9 positions. So data of table 2, as well as aforementioned data on ratio of HPDI and GNI per capita show that economic possibilities of Kazakhstan are now used ineffectively for improvement of the quality and standard of living of population.

\subsection{Approaches to Assessment of Cost of Living in the Republic of Kazakhstan}

Starting position of balanced development of human potential is achieving a certain level of economic development, provisioning of social protection of population that should be solved via a system of minimal standards.

Minimal standards are understood as statutory minimum of income and structure of socially valuable services provided to citizens. In Kazakhstan this standard is the value of the cost of living defined by the price of consumer basket. Different approaches used for calculation of the cost of living allow making opinion on social and economic situation in this or that state.

Let us consider approaches to assessment of the value of the cost of living in the Republic of Kazakhstan.

On the Cost of Living Law of the Republic of Kazakhstan (1999) defines cost of living as necessary minimal cash income per one person equal in price to minimal consumer basket that consists of food and goods. To calculate price of consumer basket that defines the cost of living combined method is used. Essence of this method is forming minimal food basket according to standards of foods consumption and price of goods (goods and services) is taken as percent of food cost calculated by statistical method. Now the share of food basket is statutory equal $60 \%$ of the price of consumer basket, relatively the price of goods and services is $40 \%$ (On 
approval of the Rules of calculation of the value of cost of living Mutual Order of the Ministry of Labour and social protection of the Republic of Kazakhstan dated December, 22005 \# 307/1-p and Statistical Agency of the Republic of Kazakhstan dated December, 52005 \# 194).

43 products were selected for minimal food basket according recommendations of the Food Research Institution with consumption standard for each demographic group: children (not older than 13 years), teenagers (14-17 years), working people (man 18-62 years, women 18-57 years) and retirees (man older than 63, women older than 58). Amount and structure of food basket are formed with account for a certain level of food, expressed in a number of calories $(2172 \mathrm{Kcal})$ as well as the other important components of food such as proteins, fats and carbohydrates.

Practically the same food basket and consumption standard are applied to all the territory of the country. Difference is only in prices. In neighboring Russia the value of the cost of living is calculated in accordance with approved by Rules of calculation of the value of cost of living in RF Order of the Government of RF dated 29.01.2013. One of important differences with the rules approved in RF is that food basket is a half of the cost of living. Usage of capacity of food basket is also slightly different and standards of consumption of foods are differentiated not only by age groups but zones that differ in natural and climate specifics affecting consumption.

Calculation of the cost of living in Russia and Kazakhstan now is made by summing up costs of necessary for living goods and services that means relating to spending of population. But in many countries including the USA calculation is based not on spending of population but earnings. Main instrument for definition of cash income necessary for minimal adequate standard of living is usually consumer budget of minimal standard of living that contains quantitative sets of goods and services and evaluated in retail prices. The level of income corresponding to poverty line is defined by triplication of the price of minimal set of products, considering that the price of food is about one third of consumer spending of a family (Hokayem \& Heggeness, 2014). Poverty line in Kazakhstan is only $40 \%$ of the cost of living that does not provide even food needs of people. In 2013 volume of food basket of Kazakhs was 10673 tenge and poverty line was 7115 tenge (Preliminary data for 2013, 2014).

So one may conclude that the value of the cost of living in the Republic of Kazakhstan does not correspond to the cost of worthy life of population of the country that is aimed on entering 30 top developed countries of the world.

One of the main factors that promote increase of standard of living of population is scientifically grounded method of its calculation.

Some scientists in their studies emphasize on: the need to reduce poor people, improving nutrition, reducing mortality - Alter, George C. (2004); improving the quality of life in terms of environmental degradation - Peter O. Olapegba, Shyngle K. Balogun, Nicola F. De Paul Chism (2012); assessing the impact of public policies efficiency on living standards - Ogwumu O. D., Adeboye K. R., Emesowum C. E., Adeyefa E. O. (2013); determination of the minimum and maximum possible level of life - Ogwumu, David O., James Friday E. (2013).

To improve method of calculation of standard of living we propose the following complex approach that allows defining optimal values of standard of living indicators with account for satisfaction of people's needs in food and really possible income level.

This approach includes three related steps.

1) Calculation of optimal consumer goods that is the base for definition of the value of the cost of living with account for satisfaction of physiological needs of a person and minimization of spending for these purposes;

2) Revealing factors that have the greatest impact on standard of living of population;

3) Calculation of optimal values of important factors of standard of living of population.

\section{Results of Calculation Based on Proposed Approach to Definition of Standard of Living of Population}

\subsection{Analysis of Results of Calculation of Food Basket}

Calculations were made for the case of Kostanay region of the Republic of Kazakhstan.

Developed optimization model accounts for the requirement that the set of food product of food basket provides average per capita need in energy $2670 \mathrm{kcal}$ a day recommended by the Kazakh Academy (Improvement of methodic of cost of living definition in the part of food consumer basket considering necessities and requirements of women and children, 2012). To compare according FAO-Food and Agriculture Organization 
men should get in average $2700 \mathrm{kcal}$ per day with food and women-2500 kcal per day (Human Energy Requirements, 2001).

Significant drawback of the method of forming food baskets of CIS countries including Kazakhstan is carbohydrates basket with low meat, milk products, fish, vegetable oil, vegetables and fruits intake. So in definition of the structure of food basket is based on the structure of food basket in Canada.

As it was mentioned earlier statutory consumer basket of Kazakhs does not correspond to the task of dynamic development of the country because keeps all the features of "survival model" with main share of spending (60\%) for food that is typical for underdeveloped countries and does not correspond to actual structure of spending of population. So practically developed (in dynamics for 2008-2013) structure of spending for food and goods and services that is in average $43 \%$ and $57 \%$, respectively, is used in the model for consumer basket calculation. Results of optimization calculations are shown in Table 3.

According to Table 3 structure of food basket obtained as a result of optimization calculation allows satisfying minimal needs and provides higher quality food. Let us make comparative analysis of optimal food basket.

Table 3. Structure of food basket in Kostanay region

\begin{tabular}{llll}
\hline Product groups & $\begin{array}{l}\text { Minimal consumption } \\
\text { rate a year, kg }\end{array}$ & $\begin{array}{l}\text { Actual consumption in } \\
2013, \mathrm{~kg}\end{array}$ & $\begin{array}{l}\text { Optimal } \\
\text { consumption, } \mathrm{kg}\end{array}$ \\
\hline $\begin{array}{l}\text { Bread (bread, alimentary paste } \\
\text { terms of flour, cereals, flour) }\end{array}$ & 108.1 & 119.9 & 108.1 \\
potatoes & 95 & 50.9 & 95 \\
Vegetables & 90 & 76.2 & 95.062 \\
Fruits & 32 & 48.2 & 105.27 \\
Meat foods & 41.7 & 67.9 & 57.42 \\
Fish & 8.4 & 12.8 & 8.4 \\
Eggs & 7.81 & 10.3675 & 8.932 \\
Milk products & 227.3 & 202.3 & 227.3 \\
Vegetable oil & 9 & 16.5 & 13.398 \\
Sugar & 18 & 37.7 & 18 \\
Other (tea) & 2.93 & 2.93 & 2.93 \\
Potable water & - & - & 365 \\
\hline
\end{tabular}

* Note: Based on sources (On approval of the Rules of calculation of the value of cost of living per capita and for main social and demographic groups of population in Russian Federation in general Order of the Government of RF dated 29.01.2013, Preliminary data for 2013)

Table 4. Structure of food baskets in Kazakhstan, Russia and Canada

\begin{tabular}{lllllll}
\hline $\begin{array}{l}\text { Product } \\
\text { groups }\end{array}$ & $\begin{array}{l}\text { Consumption structure, \% } \\
\text { Minimal, recommended } \\
\text { Kazakhstan Food Academy }\end{array}$ & by $\begin{array}{l}\text { Actual, Kostanay } \\
\text { region, 2013 }\end{array}$ & Optimal & $\begin{array}{l}\text { Minimal, } \\
\text { Russia }\end{array}$ & $\begin{array}{l}\text { Minimal, } \\
\text { Canada }\end{array}$ \\
\hline Potatoes & 16.9 & 18.6 & 14.6 & 16.9 & 13.2 \\
Vegetables & 14.8 & 7.9 & 12.8 & 11.2 & 12.7 \\
Friuts & 14.1 & 11.8 & 12.8 & 14.7 & 14.9 \\
Meat foods & 5.0 & 7.5 & 14.2 & 7.7 & 16.5 \\
Fish & 6.5 & 10.5 & 7.8 & 7.5 & 10.0 \\
Eggs & 1.3 & 2.0 & 1.1 & 2.6 & 0.8 \\
Milk & 1.2 & 1.6 & 1.2 & 1.5 & 1.4 \\
products & & & & & \\
Vegetable & 35.5 & 31.3 & 30.7 & 32.7 & 25.3 \\
oil & 1.4 & 2.6 & 1.8 & 1.6 & 2.1 \\
Sugar & 2.8 & 5.8 & 2.4 & 3.0 & 2.1 \\
Other (tea) & Potable & 0.5 & 0.5 & 0.4 & 0.6 & 1.0 \\
water & 100 & 100 & 100 & 100 & 100 \\
Total & & & & & \\
\hline
\end{tabular}


According to Table 4, greatest specific weight in Russian food basket has milk and milk product-32.6\%, vegetables (including potatoes)- $25.9 \%$, bread- $16.9 \%$. The same situation is with recommended by Kazakhstan Food Academy food basket of Kazakhs: milk and milk products-35.5\%, vegetables (including potatoes)-28.9\%, bread-16.9\%. Food basket in Kostanay region differs slightly. Vegetables (including potatoes) are in the first place in food basket in Canada-27.6\%, then milk and milk products- $25.4 \%$, fruits- $16.5 \%$ and bread- $13.2 \%$. Specific weight of vegetables, fruits, milk products and vegetable oil is high-59\%, share of meat products is also big.

Food basket obtained as a result of optimization calculation presupposes increase of specific weight of such product as fruits, meat products, vegetable oil by 9.2 percentage points, 2.3 percentage points and 2 percentage points, respectively. Structure of optimal food basket is maximally close to the structure of food basket in Canada. So optimal basket is more oriented on provisioning of healthy rational food by its structure.

\subsection{The Analysis of Results of Calculations of a Consumer's Basket}

Value of such food basket will be 14833.7 tenge a month, that is 4964.3 tenge, or $50.3 \%$ greater than actual cost of food basket in Kostanay region and 4160.3 tenge or 39\% greater than average Kazakhstan food basket (Table $5)$.

Table 5. Price and structure of food baskets in Kostanay region and Kazakhstan average (monthly average)

\begin{tabular}{|c|c|c|c|c|c|c|}
\hline \multirow[t]{2}{*}{ Indicators } & \multicolumn{2}{|c|}{$\begin{array}{l}\text { Price of food part } \\
\text { of consumer } \\
\text { basket }\end{array}$} & \multicolumn{2}{|c|}{$\begin{array}{l}\text { Price of goods and } \\
\text { services of consumer } \\
\text { basket }\end{array}$} & \multirow{2}{*}{$\begin{array}{l}\text { Price of } \\
\text { consumer } \\
\text { basket, tenge }\end{array}$} & \multirow{2}{*}{$\begin{array}{l}\text { Average monthly income } \\
\text { spent for consumption, in } \\
\text { average per capita, tenge }\end{array}$} \\
\hline & tenge & $\%$ & tenge & $\%$ & & \\
\hline Optimal & 14833.7 & 43 & 19663.28 & 57 & 34496.98 & - \\
\hline $\begin{array}{l}\text { Actual in } \\
\text { Kostanay region, } \\
2012\end{array}$ & 9318 & 60 & 6212 & 40 & 15530 & 31759.08 \\
\hline $\begin{array}{l}\text { Actual in } \\
\text { Kostanay region, } \\
2013\end{array}$ & 9869.4 & 60 & 6579.6 & 40 & 16449 & 34783.5 \\
\hline $\begin{array}{l}\text { Actual in } \\
\text { Kazakhstan, } \\
2012\end{array}$ & 10089 & 60 & 6726 & 40 & 16815 & 51594 \\
\hline $\begin{array}{l}\text { Actual in } \\
\text { Kazakhstan, } \\
2013\end{array}$ & 10673.4 & 60 & 7115.6 & 40 & 17789 & 56520 \\
\hline
\end{tabular}

Note: Cost of food and goods and services parts of consumer basket in Kostanay region and Kazakhstan is calculated basing in statutory ratio. (Based on sources Preliminary data for 2013, 2014; Spending and earnings of households of Kostanay Region, 2013; Living standard of population of Kostanay region in 2008-2012, 2013)

According to Table 5, price of minimal consumer basket grown from month to month but growth rate is significantly lower than that of optimal. Main reason is low income of medium- and low-paid strata that should be increased at least twice. This problem is very important because $57.6 \%$ of population of Kostanay region has income lower that average (3175908 tenge) in 2012.

\subsection{Analysis of Results of Calculation of Consumer Basket and Important Factors that Define Standard of Living of Population}

In the second step of we reveal factors having greatest impact in standard of living of Kostanay region population basing on correlative-regression analysis. We used statistical data for 9 years from 2004 to 2013 by a number of indicators that define standard of living of population. The most important factors that define standard of living of population are: earnings spent for consumption, price of food basket and goods and services, life span index and education level index, gross regional product per capita, share of population with income low than the price of food basket and cost of living, Integral indicator of human potential development index (HPDI) was taken as resulting factor characterizing standard of living of population. 
Table 6. Actual and optimal values of standard of living factors of population of Kostanay region

\begin{tabular}{llll}
\hline Indicators & Actual value, 2013 & Optimal value & Deviation \\
\hline Income spent for consumption in average per capita, tenge & & & \\
A year & 417402 & - & 32598 \\
A month & 34783.5 & 37500 & 2716.5 \\
Food basket cost, tenge & & & \\
A year & 118432.8 & 214041 & 95608.2 \\
A month & 9869.4 & 17836.75 & 7967.35 \\
Price of goods and services basket, tenge & & & \\
A year & 78955.2 & 235959 & 157003.8 \\
A month & 6579.6 & 19663.25 & 13083.65 \\
Price of consumption basket, tenge & & & \\
A year & 197388 & 450000 & 252612 \\
a month & 16449 & 37500 & 2105 \\
Average monthly cost of living, tenge & 16449 & 37500 & 21051 \\
Life span index & 0.72 & 0.72 & - \\
Education level index & 0.88 & 0.9 & 0.02 \\
Gross regional product index & 0.75 & 0.93 & 0.18 \\
Human potential development index & 0.78 & 0.85 & 0.07 \\
Share of population with income lower that food price, \% & 0.2 & 0.7 & 0.5 \\
Share of population with income lower than cost of living, \% & 2.6 & 9.7 & 7.1 \\
\hline
\end{tabular}

In the third step the model for definition of optimal values of these factors was formed. These values are accepted as variables and human potential development index as a target function.

Considering ratio of important indicators of standards of life the following groups of restrictions were formed:

1) By calculation of income spent for consumption;

2) By calculation of food and goods and services basket price;

3) By calculation of indices of gross regional product, education and life span;

4) By calculation of the share of population with income lower than cost of living and cost of food basket.

Cost of consumer basket in this step was defined considering optimal values of food and goods and services parts of consumer basket calculated in the first step and actual income spent for consumption by population of Kostanay region in 2013 according Department of Statistics of Kostanay region (Spending and earnings of households of Kostanay Region, 2013).

Average values for 9 years and correlation of these indices with income spent for consumption were considered in forming restrictions by calculation of optimal values of education index, gross regional product, life span.

Actual and optimal values of standards of living factors are shown in Table 6.

Calculation has shown that maximal value of HPDI in Kostanay region possible in the present stage of economic development may be 0.85 (that corresponds to standard of living higher than average), life span index 0.72 , education level index 0.9 , gross regional product index 0.93 . Monthly average price of food basket will be 17836.75 tenge, price of goods and service basket-19663.25 a month. So price of consumer basket or cost of living of Kostanay region should be 37500 tenge a month that is almost 1.9 times higher than 19966 tenge approved as price of living for 2014 by On the Budget of Republic for 2013-2015 Law.

Due to the growth of the cost of living share of population with earnings lower that the price of food basket and cost of living up to 0.7 and 9.7 , respectively.

\section{Discussion}

Compared with other CIS countries Kazakhstan citizens live relatively well-cost of living is slightly higher than \$113. Only Russia with $\$ 193$ and Ukraine with $\$ 174$ are ahead (What is included in consumer basket?, 2012), but amount of product and services that may be bought with this cost of living is different in different countries in post-Soviet space. As it was mentioned earlier base of the cost of living in CIS countries is food basket that is 
$50-60 \%$ of the cost of living and in developed countries main share of the cost of living are goods and paid services. For example, food basket in the USA consists of 16 products but consumer basket included 300 positions with clothing, footwear, payment for dwelling, mobile communications and internet, tobacco goods and beverage foods. In Canada goods and services basket includes fee for three-four bed apartment, transportation costs, phones, furniture, etc. (48 positions) (Sylvie, Cotton, \& Bishop, 2004; ILO Decent Work Technical Support Team and Country Office for Eastern Europe and Central Asia, 2012).

Information that consumer basket in Kazakhstan will be reviewed is published in media from time to time. "Parameters of consumer basket will be reviewed in 2013", said vice-minister of labour and social protection Serik Akhmetov in the sitting of Mazhilis committee (www.zonakz.net/articles/55056). According to Akhmetov revisions to the structure of consumer basket are also planned. Food part will be reduced to $55 \%$, and goods and services part to 45\%. Head of Kazakhstan Food Academy Satbek Musabekov said that to 2014 "it is planned to revise the structure of food basket provided that this work is funded" (http://kapital.kz/economic/26782/potrebitelskaya-korzina-mozhet-byt-peresmotrena.html). According to Musabekov Kazakhstan Food Academy has planned to increase assortment of vegetables and fruits that promote compensating the lack of vitamins and minerals in ration. List of products should be increased from 43 positions to 50 .

Although is it just a project one may say that changes to the structure and composition of consumer basket would not solve the problem completely. Structure of consumer basket is not that important to people of Kazakhstan because everybody buys products depending on the income and preferences. But resulting price of minimal consumer basket should be grounded because a number of basic social provisions depend on it. So scientific approach should be used in forming consumer basket together with established structure of consumption of population. So using proposed model for these purposes is preferable and grounded.

\section{Conclusion}

Comparing the cost of living in Kostanay region in 2013 that is $\$ 3.6$ per person a day (\$3.9) with international poverty line defined by the World Bank for CIS countries that is $\$ 4.3$ a day we note that the cost of living calculated by proposed method and with account for the growth of dollar exchange rate is $\$ 6.8$ per person a day.

So standard of living in Kostanay region is low despite classification of the World Bank that considers Kazakhstan as a country with high level of income and to countries with medium standard of living by human potential development index. So as it was mentioned earlier in the analysis of countries by GNI and HPDI, economic potential of Kostanay region is used insufficiently for provisioning wealthy standard of living.

On his presentation of the new consumer basket in the parliament expert of Kazakhstan Food Academy Musa Aitzhanov said that while existing food basket that includes 43 positions costs 10 thousand tenge the cost of the new basket will be more that 15,926 tenge. It means that cost of living will be close to 26 thousand tenge (Levyikina, 2013). One may fully agree with this conclusion. HPDI and GNI dynamics and our calculations show that Kazakhstan and Kostanay region has a potential sufficient for the growth of food basket and consumer basket as a whole. It is necessary to use existing potential more effectively and shift priorities to increase of standard of living of population.

So statutory and actual cost of living does not provide real cost of "survival" of an average citizen with existing costs. To make minimal social standard corresponding to the concept "cost of living" it is necessary to account for not only physiological needs of people in food but to achieve a certain level of social and spiritual needs of a man, increase the list of non-food needs of population of the country such as spending for education and health protection, healthy food, satisfying intellectual and information requirements. It is necessary also to increase gradually the quality of standards of quality life that is related to the growth of economy.

Approach to defining of standard of living proposed in this paper allows defining maximal possible cost of living in connection with integral indicator of standard of living human potential development index considering economical possibilities of the region. It has universal character and may be used for analysis and planning standard of living in regional and country level.

In this connection it is planned to make calculations for other regions and Kazakhstan as a whole.

\section{References}

Address of the President of the Republic of Kazakhstan. The Leader of Nation Nursultan Nazarbayev to the people of Kazakhstan (Strategy Kazakhstan-2050: The New Political Course of Matured State). Retrieved March 15, 2015, from http://www.akorda.kz/ru/page/page_poslanie-prezidenta-respubliki-kazakhstan-lidera-natsiinursultana-nazarbaeva-narodu-kazakhstana 
Alter, G. C. (2004). Height, Frailty, and the Standard of Living: Modeling the Effects of Diet and Disease on Declining Mortality and Increasing Height. Population Studies, 58(3), 265-279. http://dx.doi.org/10.1080/ 0032472042000272339

Andreeva, O. N. (2013). Methods of standard of living and the quality of life of population assessment. Oikumen. Region Studies, 2, 112-120.

Bobkov, V. N. (2009). Methodological approach to research and assessment of the quality of life and the standard of living of population of the All-Russian Center of the Standard of Living. Voronezh State University Gerald. Economics and Management, 2, 26-36.

Consumer basket will be reviewed. Retrieved July 30, 2014, from http://kapital.kz/economic/26782/ potrebitelskaya-korzina-mozhet-byt-peresmotrena.html

Human Development Report. (2011). Sustainability and Equity: A Better Future for All. Retrieved July 29, 2014, from http://hdr.undp.org/en/content/human-development-report-2011

Human Development Report. (2014). Sustaining Human Progress: Reducing Vulnerabilities and Building Resilience. Retrieved July 29, 2014, from http://hdr.undp.org/sites/default/files/hdr14-report-en-1.pdf

Human Energy Requirements. Report of Joint FAO/WHO/UNU Expert Consultation. Rome, 17-24 October 2001. Food and Nutrition Technical Report Series, FAO. Rome.

Improvement of methodic of cost of living definition in the part of food consumer basket considering necessities and requirements of women and children (p. 47). Almaty.

Kosmina, E. A. (2009). To the problem of reconstruction of human development indicators. Creative Economy, 9, 63-70.

Levyikina, M. (n. d.). What consumer basket consists of? Retrieved July 30, 2014, from http://rus.azattyq.org/ content/disputed-content-of-consumer-basket-in-kazakhstan/24906405.html

Living in Near Poverty in the United States. (1966-2012). In C. Hokayem, \& M. L. Heggeness (Eds.), Current Population Reports. Retrieved May, 2014, from http://www.census.gov/library/publications/2014/demo/ p60-248.html

Living standard of population of Kostanay region in 2008-2012. Statistical collection of the Department of Statistics of Kostanay Region of Statistical Agency of the Republic of Kazakhstan on statistics (p. 54). Kostanay.

Menshikova, M. A., \& Kopteva, K. V. (2012). Theoretical and methodological approaches to assessment of the standard of living and the quality of life of population. Kursk State Agricultural Academy Gerald, 6, 5-7.

Ogwumu, D. O., \& Friday, E. J. (2013). Mathematical Model for Determining the Effect of Government Policies on Nigerians' Standard of Living and the Achievement of Economic Comfort in Nigeria. American Journal of Applied Mathematics, 1(4), 84-91. http://dx.doi.org/10.11648/j.ajam.20130104.17

Ogwumu, O. D., Adeboye, K. R., Emesowum, C. E., \& Adeyefa, E. O. (2013). Mathematical Model for Estimating the Standard of Living of Nigerians and Achieving the First Agenda of the Vision 20; 2020. International Journal of Science Technology and Education (Mathematical theory and Modelling), 3(8), 90-96.

Olapegba, P. O., Balogun, Sh. K., \& Nicola, F. D. P. C. (2012). Modeling Perceived Quality of Life for People Living Near a Nigerian Dumpsite. International Perspectives in Psychology: Research, Practice, Consultation, 1(4), 221-235.

On approval of the Rules of calculation of the value of cost of living Mutual Order of the Ministry of Labour and social protection of the Republic of Kazakhstan dated December, 22005 \# 307/1-p and Statistical Agency of the Republic of Kazakhstan dated December, 52005 \# 194. Juridical Paper, March 10, 2006 \# 42-43 (1022-1023).

On approval of the Rules of calculation of the value of cost of living per capita and for main social and demographic groups of population in Russian Federation in general Order of the Government of RF. (2013). Collection of laws of RF, 5, 397.

On the cost of living Law of the Republic of Kazakhstan dated November 16, 1999, \# 474. Kazakhstanskaya Pravda, November 19, 1999.

Ponomariova, M. A. (2011). Definition of priorities of sustainable development of a region on the base of analysis of human potential. Modern research of social problems, 3, 23-32.

Preliminary data for 2013. (2014). Statistical collection of Statistical Agency of the Republic of Kazakhstan on statistics (p. 261). Astana.

Raitsin, V. Y. (2006). What is comprised of and how standard of living is defined. Retrieved March 15, 2014, from http://www.elitarium.ru/2006/12/11/iz_chego_skladyvaetsja_i_kak_opredeljaetsja_uroven_zhizni.

html 
Ravallion, M. (1992). Poverty Comparisons: A Guide to Concepts and Methods. Living Standards Measurement Papers, The World Bank.

Report on human development. (2013). Rise of the South. Development Program of United Nations Report. Retrieved April 25, 2014, from http://hdr.undp.org/en/media/HDR_2013_summary_RU.pdf

Reshetnikova, E. G. (2012). Urgent social institutional problems and the ways of solving them. Trade and Economic Journal of the Volga Region, 1, 44-52.

Rimashevskaya, N. M. (1988). People's welfare: Methods and methodics of research. Moscow, Nauka.

Spending and earnings of households of Kostanay Region. Statistical collection of the Department of Statistics of Kostanay Region of Statistical Agency of the Republic of Kazakhstan on statistics. Kostanai.

Structure of consumer basket will be reviewed in Kazakhstan in 2013. Retrieved July 30, 2014, from http://www.zonakz.net/articles/55056

Sylvie, M., Cotton, C., \& Bishop, K. (2004). (Exploration of methodological issues in the development of the market basket measure of low income for Human Resources Development Canada), Income Research Paper Series, 75F0002MIE2004001, Statistics Canada. Retrieved from http://www.statcan.gc.ca/pub-eng. pdf

The legatum prosperity index. Retrieved July 29, 2014, from http://media.prosperity.com/2013/pdf/publications/ PI2013Brochure_WEB.pdf

The new countries classification. Retrieved April 20, from http://www.worldbank.org/ru/news/press-release /2013/07/02/new-country-classification

Turliybekova, A. S., Ikmatova, G. S., \& Ikmatova, A. B. (n. d.). Human potential development in Kazakhstan. Retrieved April 20, 2014, from http://www.oldgroup-global.org/ru/storage_manage/download_file/31654

Vishnevskaya, N. G. (2014). Human potential development index as an indicator of the standard of living of population. Young Scientist, 1, 351-352.

What is included in consumer basket? (2012, August 15). Evening Newspaper, 333(747).

World Bank. (2005M). Millennium Development Goals: Progress and Prospects for Europe and Central Asia. Washington, D.C.

Worldwide cost of living table for 2011. Retrieved April 30, 2014, from http://gotoroad.ru/best/indexlife/2011

Worldwide cost of living table for 2012. Retrieved from http://media.prosperity.com/2013/pdf/publications /PI2013Brochure_WEB.pdf

\section{Copyrights}

Copyright for this article is retained by the author(s), with first publication rights granted to the journal.

This is an open-access article distributed under the terms and conditions of the Creative Commons Attribution license (http://creativecommons.org/licenses/by/3.0/). 